\title{
Socio-economic Inequality in Professionally Administered Topical Fluoride among Mexican Schoolchildren
}

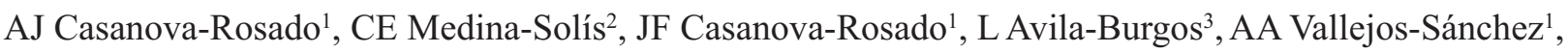 \\ S Márquez-Rodríguez², ML Márquez-Corona ${ }^{2}$, G Maupomé $e^{4,5}$
}

\begin{abstract}
Objective: To identify and characterize socio-economic inequalities in professionally administered topical fluoride treatment to schoolchildren.

Methods: One thousand six hundred and forty-four schoolchildren [6 to 13 years of age, mean $9.06 \pm 2.02$; years $50.9 \%$ boys] were included in a cross-sectional study. Using questionnaires directed to mothers/guardians, we collected sociodemographic, socio-economic and dental variables. The dependent variable was at least one professional application of topical fluoride by a dentist in the previous year. Dentists in Mexico carry out the scope of clinical care traditionally assigned to dental hygienists in the United States of America (USA) and Canada. A multivariate logistic regression model was generated.

Results: The prevalence of fluoride application was $11.5 \%(95 \% C I=9.9,13.0)$. In the multivariate model, the odds of having a topical fluoride application was higher in children who reported brushing teeth more often $(O R=1.62,95 \% C I=1.22,2.15)$ and in children from families with better socio-economic position $(O R=1.26,95 \% C I=1.06,1.50)$.

Conclusions: The experience of having fluoride administered by a dentist in the previous year was low overall in this sample of Mexican children. The results of the study suggest certain socio-economic inequalities. Strategies aimed at eliminating such inequalities across the socioeconomic spectrum are necessary if this population group is to follow recommended frequency schedules for topical fluoride applications.
\end{abstract}

Keywords: Dental care, Mexico, oral health, prevention, school, topical fluoride

\section{Desigualdad Socioeconómica en la Administración de Fluoruro Tópico entre los Escolares Mexicanos}

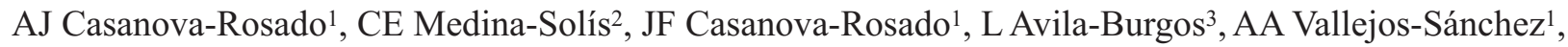
S Márquez-Rodríguez², ML Márquez-Corona², G Maupomét, 5

\section{RESUMEN}

Objetivo: Determinar y caracterizar las desigualdades socioeconómicas en la aplicación profesional de fluoruro tópico en escolares.

Material y Métodos: 1644 escolares de 6 a 13 años de edad fueron incluidos en un estudio transversal. Utilizando cuestionarios dirigidos a las madres/tutores de los niños fueron recabadas diversas variables sociodemográficas, socioeconómicas y dentales. La variable dependiente fue la aplicación profesional de fluoruro tópico, la cual fue categorizada como: $0=$ si el

From: ${ }^{1}$ Faculty of Dentistry Autonomous University of Campeche, Campeche, ${ }^{2}$ Academic Area of Dentistry, Health Sciences Institute, Autonomous University of State of Hildalgo, Pachuca, Hidalgo, ${ }^{3}$ Centre for Health Systems Research, National Institute of Public Health, Cuernavaca, Morelos, Mexico, ${ }^{4}$ Purdue University at Indianapolis School of Dentistry, In- diana University, Indianapolis, IN and ${ }^{5}$ The Regenstrief Institute, Inc Indiana, USA.

Correspondence: Dr CE Medina Solis, Avenida del Álamo 204, Fraccionamiento Paseo de los Solares. Colonia Santiago Tlapacoya. CP 42110. Pachuca de Soto, Hidalgo, México. Email: cemedinas@yahoo.com 
niño no recibió fluoruro tópico por parte de un dentista y $1=$ si el niño recibió fluoruro tópico por parte de un dentista en el año previo al estudio. En el análisis final se generó un modelo multivariado de regresión logística.

Resultados: La prevalencia de aplicación de fluoruro por parte de un dentista en el último año previo al estudio fue de 11.5\% [IC 95\% 9.9-13.0]. En el modelo multivariado se observó que los momios de tener una aplicación tópica de fluoruro por un dentista en el año previo al estudio fue mayor en los que tienen el hábito de cepillarse los dientes con más frecuencia [RM= 1.62; IC95\% = 1.22 - 2.15] y en los niños de familias con mejor posición socioeconómica [RM $=1.26 ;$ IC95\% $=1.06-1.50]$.

Conclusiones: El reporte de aplicación de fluoruro por parte de un dentista en el último año fue bajo en esta muestra de niños mexicanos. Los resultados del estudio sugieren ciertas desigualdades socioeconómicas. Estrategias destinadas a eliminar esas desigualdades en todo el espectro socio-económico son necesarias para este grupo de población siguiendo los esquemas recomendados de aplicaciones tópicas de fluoruro.

Palabras claves: Salud bucal; prevención; escolares; México

West Indian Med J 2017; 66 (2): 276

\section{INTRODUCTION}

Dental caries is one of the most common diseases of childhood despite being largely preventable, with considerable sequels such as pain and tooth loss (1). Epidemiological studies in Mexico have led to considering it a serious public dental health problem, with high prevalence and incidence in children of preschool and school ages as well as considerable unmet restorative treatment needs. Large socio-economic inequalities persist in dental caries distribution (2-5).

Based on Mexico's First National Caries Survey 2001 , the mean number of decayed, missing or filled teeth in the permanent dentition (DMFT) at 12 years of age was $1.91($ IC $95 \%=1.77,2.05)$; caries prevalence was $58 \%[95 \% \mathrm{CI}=55.7,60.3](6)$. Approximately 70 $75 \%$ of adolescents present with dental caries at age 19 years, with an average of four carious teeth $(7,8)$. Public health fluoridation in Mexico has been based on fluoridated domestic salt: between 1991 and 1993 a National Programme was developed and implemented, and by 1995 the programme became official health policy (9).

At a more individualized level, access to professional dental care affords more opportunities for prevention manoeuvers to be tailored to the individual patient (10). Periodic dental visits have been recommended by various medical and dental organizations; for example, the American Academy of Pediatrics and the American Academy of Pediatric Dentistry currently recommend that an initial oral evaluation must be scheduled within six months of the eruption of the first tooth and before 12 months of age $(11,12)$. Subsequent examinations should take place at least twice a year. One implicit assumption derived from this schedule is that both preventive and minimally invasive interventions may be optimized for the paediatric patient. While official recommendations for the Mexican environment are lacking, studies in Mexico have shown that oral health services are commonly underutilized by children and adolescents, including preventive services (13-17). A recent study showed that substantial proportions of 12-year olds have not had any contact with a dental professional (17), thereby reducing the likelihood of maintaining good oral health or reversing early-stage caries. It appears important to delineate what non-clinical features are associated with increased or decreased likelihood of timely use of oral health services: a social gradient for health has been generally accepted to exist for both general health and oral health aspects. However, published information specific to the Mexican environment is sparse. The aim of the present study was to identify the existence and determine the prevalence of socio-economic inequalities in the patterns of professional administration [based in the dental office] of topical fluoride in school age children.

\section{SUBJECTS AND METHODS \\ Population, sample and study design}

This study is part of a larger project measuring various oral health indicators among schoolchildren in Campeche, Mexico. Some aspects and methodological details have been previously published (18-20). An epidemiological cross-sectional study in children attending 
public elementary schools was conducted. The mothers of the children were contacted and apprised of the design and components of the study - including an oral examination for their children and signing of an informed consent letter. Children were excluded from the study for any of the following reasons: a) were younger than six years or over 13 years old, b) had a systemic illness that would compromise oral health, c) refused to undergo the oral examination, and d) had fixed orthodontic appliances. The final sample was 1644 .

\section{Data collection, variables of the study and creation of indicators}

Using a questionnaire addressed to the mothers, demographic, socio-economic and oral health behaviour variables were collected. The dependent variable in this analysis was the prevalence of topical fluoride application administered by a dental professional during the year prior to the study, which was categorized as: $0=$ not in the last year, and $1=$ at least once during the year prior to the study. The independent variables were gender, age, family size, frequency of tooth brushing, as well as maximum levels of education and the occupation of both parents.

Using educational level and occupation of parents, children were assigned a socio-economic position (SEP), based on principal component analysis [polychoric correlation, which allows to incorporate categorical variables]. Two indicators, one for parental education (SEP1) and another for occupation (SEP2) were generated, explaining $70.9 \%$ and $56.8 \%$ of the variability, respectively.

\section{Statistical analysis}

In the univariate analysis, we calculated frequencies and percentages for categorical variables and mean \pm standard deviation for continuous variables. Then, in the bivariate analyses, we used logistic regression. We subsequently conducted a multivariate binary logistic regression analysis to estimate the strength of association between having had any topical application of fluoride during the year prior to the study and the independent variables, expressed as odds ratios with $95 \%$ confidence intervals; $p$-values were considered statistically significant if less than 0.05 . In order to control for confounding factors, we included in the final model those variables that in bivariate analyses had a value of $p<0.25$. We estimated the variance inflation factor (VIF) to detect and avoid multicollinearity between independent variables. The model was fitted using the goodness of the fit test of Hosmer and Lemeshow, using a cut-off of $p<0.10$ as an appropriate adjustment. Confidence intervals were calculated using robust standard errors (21). Since data were from children attending the same elementary schools (cluster), we assumed that the observations within these clusters could be correlated while observations between clusters would not. Analyses were performed using the STATA 9.0 statistical programme.

\section{Ethical aspects}

This study complied with the specifications for the protection of research participants and adhered to the ethical regulations in force at the Autonomous University of Campeche, Mexico, and the principles of Helsinki. Parents/guardians of the participants signed an informed consent letter; data were treated confidentially.

\section{RESULTS}

\section{Basic results}

Descriptive results are in Table I. The sample included in this study were 1644 schoolchildren, 6 to 13 years old; $50.9 \%$ were boys. Overall mean age was $9.06 \pm 2.02$ years. On average, fathers had 7.00 years of schooling and mothers had 6.56. The average number of children per family was 3.65. Socio-economics position variables [occupation and education of parents] were divided in half as high and low. A 49.8\% prevalence of tooth brushing (at least once per day) among schoolchildren was reported. Based on reports from the mother, only $11.5 \%$ $(95 \%$ CI 9.9, 13.0) of the children received at least one topical application of fluoride by a dental professional in the year prior to the study. Please note that the dental hygiene profession in Mexico is virtually non-existent with dentists delivering services that usually make-up the scope of clinical care for dental hygienists in the USA and Canada.

\section{Bivariate results}

Results of bivariate analyses are in Table II. Family size was larger among the sub-group who was less likely to have received topical applications of fluoride, compared to those children more likely to have this clinical service in the preceding year $(p<0.05)$.

Prevalence of at least one topical fluoride application in the previous year was higher in the group that brushed teeth more times per day than among those who 
Table 1: Descriptive characteristics of the children

\begin{tabular}{ll}
\hline Variable & $\mathbf{n}(\mathbf{\%})$ \\
\hline $\begin{array}{l}\text { Gender } \\
\quad \text { Boys }\end{array}$ & $836(50.9)$ \\
$\quad$ Girls & $808(49.1)$ \\
Tooth brushing & \\
$\quad$ Less than once per day & $826(50.2)$ \\
$\quad$ At least once a day & $818(49.8)$ \\
Application of topical fluoride & \\
(at least one in the preceding year) & \\
$\quad$ No & $1455(88.5)$ \\
$\quad$ Yes & $189(11.5)$ \\
Age (child) & $9.06 \pm 2.02$ \\
Number of children in the house & $3.65 \pm 1.83$ \\
Father's schooling & $7.00 \pm 4.10$ \\
Mother's schooling & $6.46 \pm 3.67$ \\
\hline
\end{tabular}

brushed less frequently $(12.3 v s 9.1, p<0.001)$. A $12.7 \%$ prevalence of topical fluoride application was observed among those children of higher SEP [in terms of occupation], compared to $10.5 \%$ prevalence among those of low $\operatorname{SEP}(p<0.01)$.

Statistically significant differences in the frequency of topical application of fluoride by a dentist in the previous year were not found for age, gender, or schooling SEP.
Table 3: Multivariate logistic regression analysis for topical fluoride application

\begin{tabular}{lcc}
\hline Variable & OR (95\% CI) & $p$-value \\
\hline $\begin{array}{l}\text { SEP (parental occupation) } \\
\quad \text { Low } \\
\text { High }\end{array}$ & $1^{*}$ & \\
Tooth brushing & $1.26(1.06-1.50)$ & 0.010 \\
$\quad$ Less than once per day & $1^{*}$ & \\
$\quad$ At least once a day & $1.62(1.22-2.15)$ & 0.001 \\
\hline
\end{tabular}

SEP: socio-economic position, estimates adjusted for age and gender, confidence intervals were adjusted for cluster (school), Goodness-offit test: Hosmer and Lemeshow $\mathrm{Chi}^{2}(8)=8.94 ; p=3473$

\section{Multivariate results}

The odds of having a topical fluoride application by a dentist in the year prior to the study were higher $(\mathrm{OR}=$ $1.62,95 \% \mathrm{CI}=1.22,2.15)$ among those who stated they brushed their teeth at least once a day compared to those who admitted brushing their teeth less often.

The probability of having fluoride administered to the child was higher in families with better SEP [occupation] $(\mathrm{OR}=1.26,95 \% \mathrm{CI}=1.06,1.50)$ than among those of lower SEP. Statistically significant differences in the frequency of topical application of fluoride by a

Table 2: Bivariate analysis between topical fluoride application by dentist in the past year and the independent variables included

\begin{tabular}{|c|c|c|c|c|}
\hline \multirow[b]{2}{*}{ Variable } & \multicolumn{2}{|c|}{ Application of fluoride } & \multirow[b]{2}{*}{ OR $(95 \%$ CI $)$} & \multirow[b]{2}{*}{$p$-value } \\
\hline & No & Yes & & \\
\hline Age & $9.07 \pm 2.02$ & $8.93 \pm 2.00$ & $0.97(0.83-1.13)$ & 0.666 \\
\hline Family size (children) & $\begin{array}{c}3.67 \pm 1.85 \\
\text { n (\%) }\end{array}$ & $\begin{array}{c}3.40 \pm 1.55 \\
\text { n (\%) }\end{array}$ & $0.91(0.84-0.98)$ & 0.023 \\
\hline \multicolumn{5}{|l|}{ Gender } \\
\hline Boys & 747 (89.4) & $89(10.6)$ & $1 *$ & \\
\hline Girls & $708(87.6)$ & $100(12.4)$ & $1.18(0.87-1.61)$ & 0.276 \\
\hline \multicolumn{5}{|l|}{ Tooth brushing } \\
\hline Less than once per day & $751(90.9)$ & $75(9.1)$ & $1 *$ & \\
\hline At least once a day & $704(86.1)$ & $114(13.9)$ & $1.62(1.28-2.05)$ & 0.000 \\
\hline \multicolumn{5}{|l|}{ SEP (Parental schooling) } \\
\hline Low & $734(89.3)$ & $88(10.7)$ & $1 *$ & \\
\hline High & $721(87.7)$ & $101(12.3)$ & $1.17(0.88-1.54)$ & 0.273 \\
\hline \multicolumn{5}{|l|}{ SEP (Parental occupation) } \\
\hline Low & $793(89.5)$ & $93(10.5)$ & $1 *$ & \\
\hline High & $662(87.3)$ & $96(12.7)$ & $1.24(1.05-1.45)$ & 0.009 \\
\hline
\end{tabular}

SEP: socio-economic position 
dentist in the previous year were not found for age, gender, schooling SEP, or number of children in the family.

\section{DISCUSSION}

Only $11.5 \%$ of children had received at least one fluoride topical application by a dentist in the previous year; those children who brushed their teeth more frequently and those who had better socio-economic position [as measured by parental occupations] were more likely to receive the application. These trends are important to gauge overall potential for caries prevention as it has been well-established that use of fluoride technologies is associated with a decline in dental caries around the world (22).

Because of the post-eruptive pathway of action generally accepted for fluorides to prevent caries, the use of topical fluoride may afford additional coverage for people in either industrialized countries or in less-developed countries, usually taking into consideration personal caries risk $(23,24)$. While the decline in dental caries within some population groups in many countries is in itself encouraging, it is worthwhile to keep in perspective international differences for patterns of dental visits. In developed countries regular dental visits are often associated with lower caries risk (25), whereas in several Latin American countries (including Mexico) it has been observed that more frequent or recent dental visits may be associated with higher caries rates $(26,27)$ presumably due to differences in the reasons for using dental services. Visits to the dentist for preventive reasons, such as to receive topical fluoride applications, make-up a small proportion of the services provided in publicly funded health facilities and in private practice in Mexico (13-17). In countries such as Nicaragua, only $3.1 \%$ of schoolchildren ages 6-12 years had dental visits for preventive reasons (28). The driving forces for seeking dental care appear to be moderated by behaviours derived from parental characteristics.

Ideally, health services targeting a population group should be designed based on the health profile and healthcare needs [access and utilization equality considerations] and incorporate the ability to pay at point of service [financial equality considerations] (29). The reality is that many persons with unmet needs do not seek regular dental care because of financial limitations to purchase care at point of service (30). This is a major challenge to the Mexican healthcare system: to reduce oral health disparities regardless of reasons being attributed to behavioural or socio-economic factors. The social gradient in accessing topical fluoride services we have out- lined in the present study resembles other reports that substantiate consistent patterns of social gradient governing oral health features $(31,32)$ and access to dental care $(32,33)$. At the extreme of the SEP spectrum, barriers posed by the cost of dental care can be nearly impossible to overcome (34).

Adherence to a consistent pattern of tooth brushing with fluoride toothpaste is widely credited with being efficacious, cost-effective and acceptable to most (35). Our finding that better self-reported patterns of tooth brushing were associated with a higher likelihood of having received a topical fluoride application in the preceding year substantiates the perception that health behaviours may be 'bundled' in positive and negative arrays $(31,33)$. Data and results from the present study must be cautiously interpreted to avoid making unwarranted extrapolation of conclusions. Because of its cross-sectional nature, the present study may not allow drawing causeeffect inferences; the temporality of the variables observed cannot be unequivocally established, as longitudinal study designs could allow. Any retrospective data collection by means of self-reported data is open to recall bias; while often used for health research surveys, we cannot establish how likely some participants might under-state or over-state their behaviours. Despite these potential weaknesses, this is probably the first research study addressing prevalence of topical fluoride applications on schoolchildren in Mexico, as well as the associated factors moderating such experiences.

In conclusion, only $11.5 \%$ of children surveyed had experience of clinical delivery of topical fluoride by a dental professional in the preceding year. Children whose mothers indicated they had better tooth brushing patterns and whose socio-economic position was deemed to be better, had a higher likelihood of receiving this standard preventive manoeuver. Strategies aiming at eliminating such disparities across the socio-economic spectrum are necessary if this population group is to follow recommended frequency schedules for topical fluoride applications.

\section{REFERENCES}

1. Walsh T, Worthington HV, Glenny AM, Appelbe P, Marinho VCC, Shi X. Fluoride toothpastes of different concentrations for preventing dental caries in children and adolescents. Cochrane Database Syst Rev 2010; CD007868.

2. Maupome G, Martínez-Mier EA, Holt A, Medina-Solís CE, Mantilla-Rodríguez A, Carlton B. The association between geographical factors and dental caries in a rural area in Mexico. Cad Saude Publica 2013; 29: 1407-14.

3. García-Pérez A, Irigoyen-Camacho ME, Borges-Yáñez A. Fluorosis and dental caries in Mexican schoolchildren residing in 
areas with different water fluoride concentrations and receiving fluoridated salt. Caries Res 2013; 47: 299-308.

4. Zuñiga-Manriquez AG, Medina-Solís CE, Lara-Carrillo E, Márquez-Corona ML, Robles Bermeo NL, Scougall-Vilchis RJ et al. Experiencia, prevalencia y severidad de caries dental asociada con el estado nutricional en infantes mexicanos de 17 a 47 meses de edad. Rev Invest Clin 2013; 65: 228-36.

5. Medina-Solís CE, Pontigo-Loyola AP, Mendoza-Rodríguez M, Lucas-Rincón SE, Márquez-Rodríguez S, Navarrete-Hernandez JJ et al. Treatment needs for dental caries, restorative care index, and index of extractions in adolescents 12 to 15 years old. West Indian Med J 2013; 62: 636-41.

6. Ministry of Health. National Caries Survey 2001. Secretaría de Salud 2006.

7. García-Cortés JO, Medina-Solís CE, Loyola-Rodriguez JP, Mejía-Cruz JA, Medina-Cerda E et al. Experience, prevalence and severity of dental caries of Mexican adolescents and young adults. Rev Salud Pública (Bogotá) 2009; 11: 82-91.

8. García-Cortés JO, Mejia-Cruz JA, Medina-Cerda E, Orozco-De la Torre G, Medina-Solís CE, Márquez-Rodriguez S et al. Experience, prevalence, severity, treatment needs for dental caries and care index in Mexican adolescents and young adults. Rev Invest Clin 2014; 66: 505-11.

9. AMISAC. Regulatory evolution of salt fluoridation in Mexico. Mexican Salt Industry Association A.C. Available in: http://www. amisac.org.mx/index archivos/29.htm Accesed [Novenber 10 2013].

10. Beil HA, Rozier RG. Primary health care providers' advice for a dental checkup and dental use in children. Pediatrics 2010; 126: e435-41.

11. American Academy of Pediatrics. Oral health risk assessment timing and establishment of the dental home. AAP Policy Statement. Pediatrics. 2003; 111: 1113-6.

12. American Academy of Pediatric Dentistry, Council on Clinical Affairs. Policy on the dental home. 2010. [Internet] Disponible en: www.aapd.org/media/Policies_Guidelines/P_DentalHome. pdf. Consultado el 12 de julio de 2011.

13. Medina-Solís CE, Maupomé G, Avila-Burgos L, Hijar-Medina M, Segovia-Villanueva A, Pérez-Núñez R. Factors influencing the use of dental health services by preschool children in Mexico. Pediatr Dent 2006; 28: 285-92.

14. Medina-Solís CE, Villalobos-Rodelo JJ, Márquez-Corona ML, Vallejos-Sánchez AA, López Portillo-Núñez C, CasanovaRosado AJ. Socioeconomic inequalities in the use of dental services: a study of Mexican schoolchildren aged 6 to 12 years. Cad Saude Publica 2009; 25: 2621-31.

15. Pontigo-Loyola AP, Medina-Solís CE, Márquez-Corona ML, Vallejos-Sánchez AA, Minaya-Sánchez M, Escoffié-Ramirez M et al. Influence of predisposing, enabling, and health care need variables on the use of dental health services among Mexican adolescents from a semi-rural location. Gac Med Mex 2012; 148: 218-26.

16. Vallejos-Sánchez AA, Medina-Solís CE, Minaya-Sánchez M, Villalobos-Rodelo JJ, Márquez-Corona ML, Islas-Granillo H et al. Maternal characteristics and treatment needs as predictors of dental health services utilisation among Mexican school children. Eur J Paediatr Dent 2012; 13: 307-10.

17. Jiménez-Gayosso SI, Medina-Solís CE, Lara-Carrillo E, Scougal-Vilchis RJ, De la Rosa-Santillana R, Marquez-Rodriguez S et al. Socioeconomic inequalities in the oral health services uti- lization any time in their lives for Mexican schoolchildren 6 to 12 year olds. Gac Med Mex 2015; 151: 27-33.

18. Casanova-Rosado AJ, Medina-Solís CE, Casanova-Rosado JF, Vallejos-Sánchez AA, Martinez-Mier EA, Loyola-Rodriguez JP et al. Developmental enamel defects (DED) in permanent teeth associated to DED in the primary dentition. Eur J Paediatr Dent 2011; 12: 155-8.

19. Casanova-Rosado AJ, Medina-Solís CE, Casanova-Rosado JF, Vallejos-Sánchez AA, De la Rosa Santillana R, Mendoza-Rodríguez $\mathrm{M}$ et al. Dental fluorosis prevalence in eight cohorts of Mexicans born during the implementation of the Fluoridated Domestic Salt National Program. Gac Med Mex 2013; 149: 27-35.

20. Casanova-Rosado AJ, Medina-Solís CE, Casanova-Rosado JF, Vallejos-Sánchez AA, Minaya-Sánchez M, Mendoza-Rodríguez $\mathrm{M}$ et al. Toothbrushing frequency in Mexican schoolchildren and associated socio-demographic, socioeconomic and dental variables. Med Sci Monit 2014; 20: 938-44.

21. Hosmer DW, Lemeshow S. Applied logistic regression 2da ed. New York; Jonh Wiley and Sons Interscience Publication: 20001392.

22. Ferreira RG, Marques RA, Menezes LM, Narvai PC. [Multiple aspects of the use of fluorine in public health from the viewpoint of healthcare leaders]. Cien Saude Colet 2013; 18: 2139-46.

23. Oganessian E, Lencová E, Broukal Z. Is systemic fluoride supplementation for dental caries prevention in children still justifiable? Prague Med Rep 2007; 108: 306-14.

24. Weyant RJ, Tracy SL, Anselmo TT, Beltrán-Aguilar ED, Donly KJ, Frese WA et al. Topical fluoride for caries prevention: Executive summary of the updated clinical recommendations and supporting systematic review. J Am Dent Assoc 2013; 144: 1279-91.

25. Bissar A, Schiller P, Wolff A, Niekusch U, Schulte AG. Factors contributing to severe early childhood caries in south-west Germany. Clin Oral Investig 2014; 18: 1411-8.

26. Pontigo-Loyola AP, Medina-Solis CE, Borges-Yáñez SA, PatiñoMarín N, Islas-Márquez AJ, Maupomé G. Prevalence and severity of dental caries in adolescents ages 12 and 15 living in communities with various fluoride concentrations. J Public Health Dent 2007; 67: 8-13.

27. Costa SM, Vasconcelos M, Abreu MHNG. High dental caries among adults aged 35 to 44 years: case-control study of distal and proximal factors. Int J Environ Res Public Health 2013; 10: 2401-11.

28. Medina-Solis CE, Maupomé G, Herrera MS, Avila-Burgos L, Pérez-Núñez R, Lamadrid-Figueroa H. Dental health services utilization in children 6-12 year old in a low-income country. J Public Health Dent 2008; 68: 39-45.

29. Oliva-Sánchez PF, Jafif-Cojab M, Akkad-Schaffer I, Waliszewski-Zamorano E. Equity, public health and genomics: the legal, social and biotechnology challenge in México. Gac Med Mex 2013; 149: 562-8.

30. Luzzi L, Spencer AJ. Factors influencing the use of public dental services: an application of the Theory of Planned Behaviour. BMC Health Serv Res 2008; 8: 93.

31. Casanova-Rosado JF, Vallejos-Sánchez AA, Minaya-Sánchez M, Medina-Solís CE, De La Rosa-Santillana R, Márquez-Corona ML et al. Frequency of tooth brushing and associated factors in Mexican schoolchildren six to nine years of age. West Indian Med J 2013; 62: 68-72.

32. Macrhy RV, Tuchtenhagen S, Agostini BA, da Silva Teixeira CR, Piovesan C, Mendes FM et al. Socioeconomic and psychosocial 
predictors of dental healthcare use among Brazilian preschool children. BMC Oral Health 2013; 13: 60.

33. Barriuso-Lapresa L, Sanz-Barbero B. Multilevel analysis of the use of oral health services by the pediatric population. Gac Sanit 2011; 25: 391-6.
34. Ramraj C, Quiñonez CR. Self-reported cost-prohibitive dental care needs among Canadians. Int J Dent Hyg 2013; 11: 115-20.

35. Hernández-Martínez CT, Medina-Solís CE, Robles-Bermeo NL, Mendoza-Rodríguez M, Veras-Hernández M, De la Rosa-Santillana $\mathrm{R}$ et al. Oral hygiene customs across age and sex in 6-12 years schoolchildren. Rev Invest Clin 2014; 66: 157-63. 